http://revped.ise.ro

Print ISSN 0034-8678; Online ISSN: 2559 - 639X

\title{
THE SCHOOL - FAMILY EDUCATIONAL PARTNERSHIP
}

\author{
PARTENERIATUL EDUCATIIONAL ŞCOALĂ - FAMILIE
}

\section{Maria-Livia GÂRTU}

Journal of Pedagogy, 2017 (2), $107-123$

https://doi.org/10.26755/RevPed/2017.2/107

The online version of this article can be found at: http://revped.ise.ro/category/2017-en/

\section{(c) (1)(9)}

This work is licensed under the Creative Commons Attribution-NonCommercial-ShareAlike 4.0 International License.

To view a copy of this license, visit http://creativecommons.org/licenses/by-nc-sa/4.0/ or send a letter to Creative Commons, PO Box 1866, Mountain View, CA 94042, USA.

Published by:

\section{INSTITUTUL DE ȘTIINȚE ALE EDUCAṬIEI}

http://www.ise.ro/

Further information about Revista de Pedagogie - Journal of Pedagogy can be found at:

Editorial Policy: http://revped.ise.ro/editorial-policy/

Author Guidelines: http://revped.ise.ro/the-writer-guide-2/ 


\title{
THE SCHOOL - FAMILY EDUCATIONAL PARTNERSHIP
}

\section{Maria-Livia GÂR U*}

\begin{abstract}
The study brings to attention the issue of parenting and the school-family partnership, namely the case of young students, given the fact that their education raises more and more serious problems to their parents. They are entirely responsible for educating their children up to the school age. When the children start school, the responsibilities for their education are divided between family and school.

The school-family partnership means effective communication, clearly-defined tasks, homogeneous actions for the benefit of the child; parents must be considered as active participants in the school education considering the fact that they know their children the best.

In the past years, parenting programs are more successful than ever, by means of which educators teach parents how to raise their children with respect to positivity - Appreciative Parenting. According to it, several types of parental support are delivered: individual counselling, coaching, group counselling, parenting courses, support groups.

In order to form positive behaviours in children, both parents and educators need four elements: love, availability, direction and dosage.
\end{abstract}

Keywords: school - family educational partnership, parenting programs, appreciative parenting, child behaviour.

\section{Rezumat}

Studiul aduce în aten ie problema rolului parental şi a parteneriatului şcoalăfamilie, şi anume cazul copiilor, având în vedere faptul că educa ia lor ridică din ce în ce mai multe probleme serioase părin ilor. Aceştia sunt în întregime responsabili pentru educarea copiilor lor până la vârsta şcolară. Când copiii încep şcoala, responsabilită ile pentru educa ia lor sunt împăr ite între familie şcoală.

Parteneriatul şcoală-familie înseamnă comunicare eficientă, sarcini clar definite, ac iuni omogene în beneficiul copilului; părin ii trebuie să fie considera i participan i activi la educa ia şcolară, având în vedere faptul că aceştia îşi cunosc cel mai bine copiii.

\footnotetext{
* PhD Student, „Ion Creangă” Pedagogical State University, Chişinău, Moldova; „Mihail Andrei” Secondary School Buhuşi, Bacău, Romania; gartumarialivia@yahoo.com
} 
În ultimii ani, programele parentale cunosc un succes mai mare decât oricând, prin intermediul căruia educatorii îi înva ă pe părin i cum să-şi înve e copiii cu privire la aspectele pozitive - rolul parental apreciativ. Părin ilor le sunt oferite mai multe tipuri de sprijin parental: consiliere individuală, coaching, consiliere de grup, cursuri pentru părin i, grupuri de sprijin.

Pentru a forma comportamente pozitive la copii, atât părin ii, cât şi educatorii, au nevoie de patru elemente: dragoste, disponibilitate, direc ie şi măsură.

Cuvinte-cheie: parteneriat şcoală - familie, programe de educa ie parentală, rol parental apreciativ, comportamentul copilului. 


\section{Introduction}

In today's society the education of the children is a real challenge for parents, especially after school age. From the moment the children start school, the responsibilities of the child education are divided between parents (family) and school. School needs the family support to develop the educational act, just as parents need help from the educators. Some parents believe that they do not need to be educated, in their turn, how to educate their children, which is true in a few cases. However, most often, there is a need of training for the "job" of parent.

Where does the need of parent education come from? On the one hand, it comes from the discrepancy between what the current parents know from their parents about the child education, and on the other hand, from the children's needs regarding their relationship with the parents/ the school/ the society.

The society has changed in the past decades: every day there appears new information about children and about the different characteristics corresponding to the various stages of their biological, psychological or emotional development. Also, the mentality regarding the roles of the parents with respect to their children has changed; for example, in most families, both parents work which leads us to believe that the responsibility for child raising/ education goes to both parents, not only to the mother, as it is the case in the traditional family. Children, in their turn, tend to adapt very quickly to the social changes and the new technologies, and are less obedient to the parents with a traditional vision. They don't take anything for granted; in fact they want explanations for all the aspects of the reality they are faced with. New challenges appear and the parents need to be prepared to "offer" appropriate answers to intelligent questions. From this point of view, school is the first support of the parents.

\section{Types of school-family cooperation}

Parents interact with the school, the educators/ school counsellors, education trainers in many ways. An important concept in the modern pedagogy is the school-family educational partnership, representing a form of communication and cooperation between school and the child's family.

The connection between school and family is activated especially during primary school. This is when the problem of the educational partnership appears, which is according to Rodica Enache, "a form of communication, cooperation, collaboration in support of the child at the level of the educational process. It involves a unity of requests, options, decisions and educational actions among 
educational factors (Enache, 2011). The educational partnership is realised between:

- education institutions: family, school and community;

- educational agents: child, parents, teachers, specialists in solving educational issues (psychologists, counsellors, therapists);

- members of the community with an influence in the child raising, education and development (doctors, representatives of the church and the police); - programmes of child raising, care and education.

Among all these, the most important is the school-family partnership. This partnership involves parents (students included too) and the school staff. It is important to communicate the proposed objectives in the sense that school and family must act together; the education within the family should not contradict the education received at school. Also, nowadays, the child is part of the educational decision-making, according to his possibilities, especially since, through the educational process, the child should be responsible and able to make quick decisions (as a result of the positive education). The educational act becomes a partnership within which both the learner and the educator learns; the educator should be flexible, creative, dynamic, willing to find solutions for change.

Thus, parents collaborate with the school for the benefit of the children, for a better awareness of their needs and a better social/ school integration. The beginning of the school represents a major change, not only for the child but also for the family. The adults in the life of the children (parents, grandparents, teachers/ educators) must work together, without having prejudgments of the type: „I was educated by mother without being taught this in school”. School organises activities by means of which parents participate actively in the education of their children together with the educators. Through these activities, parents' counselling and training are achieved. The most important are:

- parent-teacher meetings, representing meetings on a certain topic, organised by the teacher with the purpose of offering the parents the possibility of interrelating, exchanging opinions and experiences, asking questions related to education, finding solutions to different problematic situations occurred within the educational process; the meetings should be held every semester or whenever it is necessary. However, parents tend to be reluctant to attending meetings with all the other parents, during which they should require guidance/ advice. When a parent has a problem to discuss, they usually wait until the meeting is over in order to discuss the matter with the teacher in private;

- parent-teacher conferences are organised by the school with the purpose 
of informing parents on the latest reports regarding child psycho-pedagogy, education and also in order to present various methods of teaching; they refer to approaching the problems in a positive manner; this is also called positive communication, positive discipline, which would seek to achieve an awareness of actions, excluding negative messages, accountability. Parents are inclined to prohibit various things to the children, which they perceive as negative messages. Parents are recommended to use positive messages (for example, a message like "You haven't tidied up your room" could be replaced with "I'm sure you can tidy up your room");

- counselling for parents towards the acquisition of certain skills, which are necessary in child education; this refers to orientation activities and parent supervision, along with individual discussions.

In the work entitled "Consilierea parentală. Ghid metodologic" ("Parenting. A Methodological Guide"), Cuzne ov (2014) presents the activities of psycho pedagogical counselling as ,,an educational-formative act centred on exercising the individual competences and availabilities", in this case - the parents. The author presents the characteristics of psycho-pedagogical counselling referring to the fact that the parent has direct contact with the school representative in order to communicate efficiently, and has the opportunity to assume certain abilities and parental competences; thus, parents learn to listen to their children more, to spend more time with them, to assign them different tasks appropriate for their age, with the purpose of educating them as responsible people.

Also, counselling can prevent certain mistakes which occur in child education (physical or verbal violence), it can teach the parents to find solutions on their own in order to solve unforeseen situations:

- "it has a preventive and developmental role": parents "learn how to prevent possible situations of crisis, learn how to find satisfactory solutions to the problems they are faced with";

- " "it is a specific educational-formative act" which has the purpose of teaching parents how to help themselves, how to find solutions;

- it implies "conscious, active and responsible involvement from the part of the family and parents" who are training to build the parenthood life (Cuzne ov, 2014).

The people responsible for psycho-pedagogical counselling are "competent and qualified people, they are called counsellors (school counsellors or educational counsellors) who intervene in family problems" (Cuzne ov, 2014). In the case of young children, the most appropriate person required to offer counselling is the educator/ primary school teacher. In order to be able to provide counselling, primary school teachers need specialised training. 
In many cases, in Romania, school counselling does not have the expected results, for many reasons: shortage of qualified personnel, respectively counsellors; the counsellors' lack of time, lack of interest from the parents with social problems and financial difficulties. A school counsellor works in more schools, having a program that does not allow them to be present in only one school unit, throughout the entire week. On the other hand, not all teachers have the required qualifications. This is the reason why the need of an educational partnership is on the agenda.

\section{The evolution of parenting in Romania}

The term "parenting" (borrowed from the English language) appeared relatively recently in modern pedagogy and it refers to a form of support given to the parents/ legal representatives in the child raising and education, from birth to adult age. Parenting helps parents to improve themselves in the educational process in order to raise happy children. In Romania, in the past years, parents have become more and more interested in parenting. From this perspective, parental education programmes have become more successful lately, by means of which parents learn to educate their children in the sense of positivity.

Within the Swiss-Romanian Cooperation Programme, Our Children Foundation in collaboration with UNICEF, FONPC and Formation des parents ch. carried out a study in 2016, as part of the project "Promoting the National Strategy for Parental Education", the second study after another one which was carried out in 2010, on a number of 1173 respondents. The study is "a research on the opinions of parents, professionals and decision-makers, regarding the parenting activity" (Preda, 2016). The study covered 16 counties and sector 5 in Bucharest, in both urban and rural backgrounds.

The conclusions show that the involvement of parents in the education of school children was low after 1989, due to the effects of communist policy prior to the revolution. The activity of parents' education began to develop in Romania in the late 1990s. Lately, lifelong training modules for accredited teachers and other child development and protection staff have also been proposed, focusing on parenting (inclusive education, socio-emotional education).

The study carried out by Our Children Foundation shows that these programs and projects developed by the Ministry of Education as a beneficiary or partner highlight some important aspects, such as: identifying the need for support granted to the parents with the purpose of reducing school failure, dropout, discrimination, violence. 
The study also shows that there is an awareness of the need for parental education, both in urban and rural areas, and that it is very important to know and respect children's rights within parent education. On the other hand, "the parent educator is regarded as a qualified professional, with long duration studies, structured and developed in an appropriate training framework" (Our Children Foundation, 2016) - according to The Law of National Education no.1/2011, section 3, art. 247, point g), with reference to psycho-pedagogical centres and offices. At the same time, the respondents considered the education provided to the parents to be very important, in various forms: counselling, more playgrounds and parental education.

When the child starts school, there appears the problem of child development and learning, and as a result the school offers "support structures for both the child and the family" (Enache, 2011). At the same time, there are activities that support parents in the educational act. In school, there are offices for psycho-pedagogical assistance, counselling, speech therapy and professional guidance (according to The Law of National Education). There are also family and / or teacher resource centres (open by the previously mentioned projects with support from UNICEF). It isn't only the family that needs help to evolve, but also the school in order that children are best educated. From this point of view, teachers have to give up the self-centred attitude, to consider themselves at the heart of the educational act. Teachers need to have a strong desire for their students to learn. For this, they need to know their pupils very well so that they can help them understand what they will learn, taking into account their individual needs. Teachers should be aware of the fact that, in order to be effective factors, they need to emphasize the purpose of learning, to be able to provide students with options, to constantly assess by various methods / means, to use educational resources effectively, to ask for and offer support to their colleagues. On the other hand, the management of the educational institution must provide teachers with safety, trust, support, methods of progress supervision.

Parents, in their turn, get involved in child schooling. They are interested in the school program, school progress and how they can help the child. Meetings between parents and school representatives are either formal, under the form of lectures, or informal, as in daily conversations with the teacher. Parents' associations have become active and started having discussions with school representatives on different aspects of school activity. The school has a partnership with parents regarding student counselling, and also other aspects.

At the level of the educational institution, several types of relationships are 
developed: the most important is the teacher-pupil relationship, then the individual relationships (between the pupils, between the teachers, the teachers and the administrative staff); relationships between parents and teachers, relationships between child development professionals and parents / teachers.

The school-family partnership means effective communication, clearly defined requirements, unitary actions in the interest of the child; parents should be considered active participants in school education because they know their children best; therefore, they must participate directly in the decision-making process; the responsibility for educating children is divided equally between parents and teachers.

The relationship between school and family has not always been considered in the form of a partnership. After 2000, studies show the influence of the family on school results, especially due to the fact that the family, as an institution, is going through a period of crisis. The most important challenge is the departure of parents to work abroad, leaving children in the care of their relatives. The school is blamed for the students' bad results, and also viceversa. In consequence, parents' associations and parents' organizations are beginning to appear, but without any involvement in the decision-making process regarding the aspects of the education. The providers of new-teacher training programs also consider the idea of introducing topics on the schoolfamily relationship. Mutual mistrust is thus removed along the way. The Teachers' Board includes parents' representatives with a decision-making role in all educational problems; parents' associations are encouraged to participate in school work. Also, teacher-training and parent-training courses are organized.

After the establishment of ARACIP - the Romanian Agency for Quality Assurance in Preuniversity Education, in 2005, a special "legitimacy" is discovered for the school-family partnership, meaning that an important aspect of the evaluation carried out by this body is the consultation of the parents' representatives with reference to the quality of the educational act in school.

\section{Obstacles and solutions in the good cooperation between school and family}

The Institute of Educational Sciences (IŞE) in Romania studied the relationship between school and family ( ibu and Goia, 2014) and observed that there are some obstacles in the school-family relationship at the behavioural level both from the teachers and parents part, especially in school areas of social and material risk, because the school-family relationship requires effort and 
additional time, both on the part of the school and the parents. A major obstacle is the mentality of parents, teachers, students, and social habits. Due to changing social contexts, as labour migration for example, nowadays many children are deprived of parental models. If problems arise in one of the two environments, the effects are noticed in the child's behaviour / attitude, but also in school results. This is the moment when accusations arise: parents are accused of not having an initiative in establishing communication with the school, of not supporting / assisting the child in doing homework, not managing correctly certain childish, rebellious manifestations, conservatism (opacity towards new ideas), excessive preoccupations for school results; teachers are criticized for the relationship with their pupils and parents, lack of adequate training to manage their relationship with the family, severe strictness or, on the contrary, too little constraint / permissiveness.

Conflicts between school and parents may arise, especially due to differences in education, mentality, perceptions and attitudes or values. Other causes can be added too: poor communication between the two institutions, poor informing, intolerance towards a certain lifestyle, a small number of meetings between parents and teachers, previous unhappy experiences in similar relationships, ignorance of responsibilities and roles assigned to every part.

These problems can be solved through: knowledge, effective communication, mutual tolerance and acceptance, evaluation of relations, cooperation in common activities, creating a positive atmosphere during meetings. Both school and family, have serious responsibilities regarding child education. That is why there is a need for a parenting school. Education institutions are called upon to include parents in the school educational act, showing them that school is a place of safety (students are protected from potential external dangers; they have a proper framework for development, they are accepted and relate to other children of the same age). The family also has certain responsibilities (to offer the children affection, support, the best living conditions).

Specifically, when there is a heated discussion between teacher and parent, the teacher has to keep calm and postpone the discussion in order to get more information about the situation in cause. The parent must be allowed to talk without being interrupted and also must be listened to, keeping a calm attitude. The teacher will initiate positive communication without making accusations, without making hasty conclusions, without judging, having a positive attitude, showing that he/she understands the role of the parent and the challenges that appear. Also, the teacher will show the parent that he/she 
is important for the teaching activity; and that accusations do not help to establish a positive parent-child relationship.

The school is the institution with the most important role in the relationship with the family, having methods to train parents in common actions for the homogenous education of children; that is why the family is informed about the purpose of the instructive-educational process, the tasks / requirements given to the children; the school also informs parents of the methods that can be used in the family to fulfil its mission. Thus, teachers educate both children and parents.

As an institution, school has specialists who contribute to building an authority in the education of both children and adults. Elisabeta Stănciulescu shows that the school identifies four ways of perceiving the family (Henripin, 1976, apud. Stănciulescu, 1997), each having distinctive features from the perspective of the importance of the two institutions: if "the family as a client" does not have a say in the relationship with the school, taking only the decisions imposed by the school, "the family as pressure group" is very active in putting a pressure in order to solve parents' claims; "the family as a guarantor" is consulted by the school, and - "the family as a partner" is actively involved in the decision-making, since the parents' representative is a member of the School Board.

The same author cites two Canadian authors, J. Comeau and A. Salomon (1994) and shows that, from the perspective of school-family relationships, there are the following types of school: "authoritarian school", which offers minimal cooperation with the family and considers that parents don't have any psycho-pedagogical training; "the participatory school" which includes the parent in the educational process; "the community school" which appeals to all the resources of the community; and "the autonomous school" which does not accept external interventions, but "exploits the pupils' participatory potential" (Stănciulescu, 1997). In order to have a good partnership between the two institutions, it is preferable to have participatory and community school.

School is an institution which provides education and, in this quality, it has resources, methods, goals, etc. that recommend it as a partner in the relationship with the family and the community (losifescu, 2001). School is the initiator of the partnership and, in order to establish a good collaboration with the family, it needs to broaden the participatory character of the school management; it also needs to attract the family as the main partner, expand 
their collaboration to all factors that can help in education. Family is attracted mainly by opening up to social changes, educating children in a positive manner.

Many parents believe that when their children start school, their role in education is highly reduced. In fact, their role becomes more important because at home they have to create a balanced environment based on trust and security on the one hand, and on the other hand, family needs to become an active member of the school community to support the educational act, both in school and at home.

Teachers must increase parents' awareness of this important role. In fact, research has shown that "in programs where parents are involved, pupils have higher school performance compared to similar programs but where parents are not involved" (UNICEF, 2006). When there is a gap between teacher and parent communication, this is reflected in the child's school results. The responsibility for the education and development of young children should be equally divided between school and family. Thus, there are several benefits: it increases the self-esteem of the children, the parents understand better what happens at school and spend more time with the child, the pupils have better results, they do their homework every day, both children and parents develop positive feelings in relation to the school. However, many parents do not have time or are unwilling to work with the school. It is the duty of the teacher to make them aware of the importance of collaborating with the educator for the child's benefit: the child has various tasks both at school and at home and that is why a similar degree of responsibility should be assigned to both the school and the parents. "The school needs to encourage and promote the involvement of parents as partners" (UNICEF, 2006).

One example of such a program is currently being developed by UNICEFRomania and the Ministry of Education. The course is held in several, including "Mihail Andrei" Secondary School in Buhuşi, Bacău County. Courses are organized for the teaching staff serving as training to learn methods, techniques in their relationship with parents and students for a positive education (which deals with the study of the qualities and virtues that help children to have positive improvements, to develop and lead a happy life).

\section{Appreciative Parenting}

Appreciative Parenting starts from the belief that parents are models that their children follow, and the family should provide a space of balance and 
should not be the place where parents' daily frustrations come to life. Selfcontrol and positive communication are needed. The aim of the program is therefore to encourage parents to analyse their lives and the relationship they have with their own children, to discover positive alternatives to parenting, to develop a social support network together with other parents. Through this program, parents become aware of the positive alternatives to educating the child, all this leading to an improvement of both their lives and their children's lives.

Within the Appreciative Parenting, there are two types of parental support: individual support and group support (HoltIS, UNICEF, 2017). The individual support is accomplished by "individual counselling", "mentoring" and "parental coaching", the later representing an "informal relationship between two people, one has more experience and expertise than the other, and provides advice and guidance" (pp.12-22). On the other hand, group interventions are of the following types:

- "group counselling" is conducted by a specialized leader who prepares the meeting with thorough attention;

- "Parental Education courses", "a prevention / intervention tool used precisely to support parents to develop healthy parenting practices";

- support groups (peer and self-help support) created on the premise that supportive interactions with people experiencing similar problems can give the individual a sense of empowerment, an increase in self-efficacy, and increase their adaptive abilities" (HoltIS, UNICEF, pp.24-31).

In the work entitled "Cum ne antrenăm Parentingul Apreciativ: Manualul Educatorului Parental" ("How to Train Appreciative Parenting: Parent Educator's Handbook", 2015), it is stated that parents are sometimes overcome by the day-to-day stress in the context of a rapid changes that require a fast adaptation to new situations. This may result in the quitting of the role of parent or the continuation of this role accompanied by behaviours that may endanger the physical and mental health of their children.

According to L. Yballe and D. O' Connor, (2000, pp.474-483), when we take into consideration children from grades I to IV, parental education is based on several principles. Those relevant in the context of our article are:

- "focusing on experience" which means to start from the previous experience of both educators and parents "about life, about themselves, parents become sources of knowledge";

- "focusing on success" which refers to "making the best use of the moments of the greatest success, pride, or glory experienced by parents"; they 
represent the inspiration for future successes if they are comprehended and amplified. During the parenting course, parents are encouraged to identify the moments of success in educating their own children, then to identify their own and their children's qualities and the way in which they led to success;

- "focusing on the connection between positive vision and positive action", by means of which a positive view of people, institutions, community, children is created and which encourages positive actions in relation to children. "The more positive the questions we ask during meetings are, the faster and more successful the social change becomes";

- "the poetic principle" refers to the fact that the family environment is under permanent construction and reconstruction, "just as a poem can be interpreted and reinterpreted" with new meanings.

\section{Applications of appreciative parenting education within a school based training course}

At the moment, the Ministry of Education, in partnership with UNICEF is implementing the Appreciative Parenting Program in several schools where there are students in difficulty due to social or financial reasons, among which there is also "Mihail Andrei" Secondary School, Buhuşi, Bacău County. Within the project, teachers are trained to prepare parents so that they can educate their children on the principle of positivity.

Parents are sometimes overcome by the day-to-day stress in the context of a rapid changes that require a fast adaptation to new situations. This may result in the quitting of the role of parent or the continuation of this role accompanied by behaviours that may endanger the physical and mental health of their children. Regarding the poor families (as it is the case of "Mihail Andrei" Secondary School), they are forced to work hard or to go abroad in order to survive. Thus, parental education has become very important nowadays for all categories of parents who need to understand their children better, to educate themselves in the benefit of their children, to learn to respect their children, the basis of positive education.

The Appreciative Parenting Course involves parents in training sessions which help them to become better parents. These sessions are carried out by parent educators (may be the teachers themselves) who in their turn are trained for this position. The course is based on Kolb's experiential learning theory (learning through exercises) so that parents can apply what they learn during the course in real-life situations. 
The first stage is to learn how to overcome stress and anger, by identifying the sources of stress/anger, its symptoms, and then by learning how to cope with stress and control anger. Parents are taught to help their children cope with anger.

The next stage is efficient / positive communication between parent and child. Through different exercises, parents experience active listening, verbal communication and means of positive communication (for example, messages of the "l" type).

In order to better understand the child, parents learn the characteristics of the child development at a young school age, including the concept of emotional intelligence. This helps parents understand certain emotional manifestations of the child and find solutions to various problems or concerns. With regard to these aspects, parents are encouraged to think, communicate and relate positively, so as to be a model for the child: to identify the causes of anger and avoid them, to avoid judging people by labelling them in front of the child, to get involved in the problems of the child by communicating positively, to engage the child in household chores, to restrict the child's access to the media, to discuss family feelings, to see the child as capable and wonderful.

During the course, parents are trained to become trustworthy partners in the relationship with their own child: they learn about the rights of the child and that these rights must be respected; it is the parent's duty to learn how to strengthen the positive relationship with the children, by spending time with them in a constructive manner, by setting priorities according to emergency situations, by co-opting the child into the decision-making process.

An important problem is disciplining the child in a positive way. Firstly, parents are invited to understand the concept of "discipline" and to eliminate the concept of punishment from their vocabulary because it is considered harmful. Discipline is presented as a form of learning and a need for setting a limit, thus the children will learn to discipline themselves. The punishment applied to children teaches them that this is the right way to treat others. Positive discipline methods are discussed: active listening, positive attention and encouragement, time spent with every child, affection. Parents' reactions to challenging behaviours must be positive too: hugs, breaks for both children and parents. Hitting and beating are presented as violent forms of reaction that prevent the child from having proper feelings of responsibility or guilt for his behaviour and prevent him from solving the problem. The possibility of learning is excluded in this way. 
Another important problem is the prevention of abuse and its effects on the child. Parents become aware of the precedence of knowing the forms of abuse on children: child neglect, neglecting their needs, verbal or physical, emotional abuse, and ignoring abuse. Also, parents learn how to observe any sign of child abuse and its effects on the child's development. This form of learning is experiential, which implies the fact that parents will understand all forms of abuse and its consequences by means of exercises.

Among the styles of parenting, the closest to positivity is the efficient one: the adult has realistic expectations from the child, offers him/her the necessary emotional support, explains the reasons for setting rules and limits, establishes a set of rules in cooperation with the child, has a firm attitude, but at the same time, encourages the child to be independent and involves him/her in the decisions that concern them. These competences/ abilities are acquired by the parents by participating in The Appreciative Parenting Course. The positive long-term effects can be observed in the development of the child's personality and in the high quality of their social skills. The children that are educated in this way will assume responsibility for their actions; will have a high degree of self-esteem and respect, will show initiative; they are also emotionally balanced, have good communication skills, are creative and positive (Cojocaru, 2015).

In order to form positive behaviours in children, both parents and educators need four elements: love (which implies forgiveness and patience); availability to be caring, to spend time with the child, to study at all times; direction towards certain goals and dosage as the ratio between what the parents should ask for and what they offer the child in return.

\section{Conclusions}

In Romania, there is an acute need for parenting, taking into account the problems the family is faced with regarding child education, in general, and young students' education, in particular. The models of parents' education acquired from parents' parents are outdated. The phrase "I educate my children just as I was educated" is no longer up to date, due to the complexity of the relationship between children and their parents, the school, the society.

School supports family, by offering professional counselling within parents' meetings, which are held either by school counsellors or teachers, but this is not sufficient. Lately, in Romania, The Ministry of Education has developed programs of parenting, in cooperation with UNICEF and NGOs: "Save the Children", "Our Children Foundation", "Holt". This kind of activity started in 
1990 and developed gradually, as a reaction to the increasing need of parents in difficulty regarding young students' education.

Appreciative Parenting promotes a number of types of activities: individual counselling, mentoring, coaching, group counselling, parenting courses, and support groups. However, in order to form positive behaviours in children, parents and teachers altogether need love, availability, direction and dosage.

\section{REFERENCES}

Cojocaru, Ş. (2015). Abordarea pozitivă a comportamentelor copilului. (Positive Approaches on Children's Behaviour), laşi: Editura Expert Projects.

Cuzne ov, L. (2014). Consilierea parentală. Ghid metodologic. (Parent Counselling. A Methodological Guide), Chişinău: Editura Primex-Com..

Funda ia Copiii Noştri (2016). Studiu de cercetare cu privire la educa_ia parentală

şi nevoia de servicii de sprijin pentru părin i (Research Study Regarding Parenting and the Need for Support Services for Parents), Bucureşti.

HoltIS, UNICEF (2015). Cum ne antrenăm parentingul apreciativ: manualul educatorului parental (Training Aprreciative Parenting: The Parent Educator's Handbook), vol. 3, laşi: Editura Expert Projects.

HoltIS, UNICEF (2017). Tipuri de suport parental. Ghid pentru încurajarea parentingului apreciativ (Types of Parental Support. A Guide for Encouraging Appreciative Parenting), laşi: Editura Expert Projects.

losifescu, Şerban (2001). Parteneriat şi implicare comunitară (Partnership and Community Involvement), Bucureşti: Editura Tipogrup Press.

Stănciulescu, E. (1997). Sociologia educa iei familiale (The Sociology of family education). vol.I. Iaşi: Editura Polirom.

ibu, S. \& Goia, D., (coord.) (2014). Parteneriatul şcoală-familie-comunitate.

Laboratorul Consiliere şi management educa_ional (School-FamilyCommunity Partnership. Laboratory of Counselling and Educational Management), Bucureşti.

UNICEF România (2006). Educa ia Părin ilor (Parents' Education), Bucureşti: Editura MarLink.

Yballe, L. \& O' Connor D. (2000). Appreciative pedagogy, in Journal of Management Education, 24 (4). Retrieved from http://citeseerx.ist.psu.edu/viewdoc/download?doi=10.1.1.629.9820\& rep=rep $1 \&$ type $=$ pdf. 


\begin{tabular}{|c|c|}
\hline $\begin{array}{l}\text { The online version of this article can be found } \\
\text { at: http://revped.ise.ro/category/2017-en/ }\end{array}$ & $\begin{array}{l}\text { Versiunea online a acestui articol poate fi găsită } \\
\text { la: http://revped.ise.ro/category/2017-ro/ }\end{array}$ \\
\hline (c) (4) (9) (2) & (c) (1) (9)(2) \\
\hline $\begin{array}{l}\text { This work is licensed under the Creative } \\
\text { Commons Attribution-NonCommercial- } \\
\text { ShareAlike } 4.0 \text { International License. }\end{array}$ & $\begin{array}{l}\text { Această operă este pusă la dispozi ie sub } \\
\text { licen a Creative Commons Attribution- } \\
\text { NonCommercial-ShareAlike 4.0 International. }\end{array}$ \\
\hline $\begin{array}{c}\text { To view a copy of this license, visit } \\
\text { http://creativecommons.org/licenses/by-nc- } \\
\text { sa/4.0/ or send a letter to Creative Commons, } \\
\text { PO Box 1866, Mountain View, CA } 94042 \text {, } \\
\text { USA. }\end{array}$ & $\begin{array}{c}\text { Pentru a vedea o copie a acestei licen e, vizita } i \\
\text { http://creativecommons.org/licenses/by-nc- } \\
\text { sa/4.0/ sau trimite i o scrisoare către Creative } \\
\text { Commons, PO Box 1866, Mountain View, } \\
\text { CA 94042, SUA. }\end{array}$ \\
\hline
\end{tabular}

